\title{
Electronic Structure of ZnS Crystal Doped with One or Two Transition Metal Atoms (Cr, Fe)
}

\author{
S.V. Syrotyuk \\ Lviv Polytechnic National University, 12, S. Bandera St., 79013 Lviv, Ukraine
}

(Received 18 June 2021; revised manuscript received 20 October 2021; published online 25 October 2021)

\begin{abstract}
The electronic and magnetic properties of $\mathrm{ZnS}$ crystal with impurities of transition $3 d$ elements $\mathrm{Cr}$ and $\mathrm{Fe}$, which replace $\mathrm{Zn}$ atoms, are calculated. The calculations are performed in $2 \times 2 \times 2$ sphalerite supercells containing 64 atoms. The same supercells, which contain both $\mathrm{Cr}$ and $\mathrm{Fe}$ impurities, are also considered. It is established that energies of $3 d$ electrons of the $\mathrm{Cr}$ atom with spin up in the $\mathrm{Zn}_{31} \mathrm{Cr}_{1} \mathrm{~S}_{32}$ supercell are localized in narrow energy intervals around the Fermi level and at the top of the valence band. For spindown states, this material exhibits the properties of a semiconductor with a direct band gap of $2.11 \mathrm{eV}$. The magnetic moment of the supercell equals to $4 \mu \mathrm{B}$. The results of the calculation for the $\mathrm{Zn}_{31} \mathrm{Fe}_{1} \mathrm{~S}_{32}$ supercell show that this material is a direct-band semiconductor with the width of the band gap at the $\Gamma$ point of about $1.96 \mathrm{eV}$. $3 d$ electrons with spin down are localized in narrow energy bands near the Fermi level and at the bottom of the conduction band. The pseudogap value for electrons with spin down is $0.53 \mathrm{eV}$. The magnetic moment of the supercell is also equal to $4 \mu \mathrm{B}$. It is found from the results of the calculation for the $\mathrm{Zn}_{30} \mathrm{Cr}_{1} \mathrm{Fe}_{1} \mathrm{~S}_{32}$ supercell that $3 d$ electrons of the $\mathrm{Cr}$ atom with spin up are localized in the vicinity of the top of the valence band and the Fermi level, which is inside the valence band. The optical gap at the $\Gamma$ point is equal to $0.60 \mathrm{eV}$ and the indirect fundamental gap $(\Gamma-\mathrm{R})$ is $0.59 \mathrm{eV}$. The pseudogap value for electrons with spin down is $0.60 \mathrm{eV}$. The magnetic moment of the supercell equals $8.04 \mu \mathrm{B}$. The calculations are performed using the ABINIT program. The hybrid exchange-correlation functional PBE0 is used to eliminate the self-interaction error of $\mathrm{Cr}$ and $\mathrm{Fe} 3 d$ electrons.
\end{abstract}

Keywords: ZnS, Sphalerite phase, Impurities of $3 d$ elements, Strong correlations, PBE0, Electronic structure.

DOI: 10.21272/jnep.13(5).05027

PACS numbers: $61.72 . \pm \mathrm{y}, 71.20 . \mathrm{Nr}, 71.55 . \pm \mathrm{i}$

\section{INTRODUCTION}

$\mathrm{ZnS}$ and ZnSe semiconductor crystals, doped with transition $3 d$ elements, have been actively studied for the last two decades as promising materials for use in laser technology [1]. The crystal ZnSe:Cr interesting for laser construction was first reported in 1996 [2]. In [2], a number of physical properties were identified that are particularly favorable for the use of these materials for the construction of lasers in the middle infrared (MIR) region. The most important among them are the following properties [1, 2]: 1) the tetrahedral coordination of $3 d$ ions causes smaller crystal-field energy splitting, compared with the octahedral one, i.e. leads to the placement of $3 d$ dopant transitions in the IR energy region; 2) II-VI crystals are transparent in a wide spectral range; 3) II-VI:3d gain media are characterized by ultra-broad MIR tunability as well as ultra-short pulse generation; 4) $\mathrm{Cr}^{2+}\left(3 d^{4}\right)$ and $\mathrm{Fe}^{2+}\left(3 d^{6}\right)$ ions are the most attractive for laser applications, because these chemically stable divalent dopant ions provide the 'right' multiplet structure for broadly tunable MIR lasers, including broad absorption and emission bands, high crosssections, and the absence of excited state absorption [1].

The search for the realistic theoretical approaches for the electronic structure description in $\mathrm{ZnX}$ crystals for today is not completed. The reason for this is that LDA (GGA) approaches do not properly account the strong correlations of the $\mathrm{Zn} 3 d$ electrons [3]. However, $\mathrm{ZnS}: \mathrm{Cr}, \mathrm{ZnS}: \mathrm{Fe}$ and ZnS:Cr:Fe materials contain $3 d$ electrons of transition elements, which is even more problematic due to strong electron correlations.

It was found that realistic band gaps, wave functions, and crystal potentials obtained with PBE0 hybrid functional [4] for the exchange-correlation energy al- lowed to obtain an electronic structure in nanostructures $[5,6]$ that shows good comparison with the experiment. The use of the PBE0 hybrid functional made it possible to compare well the parameters of the electronic energy spectrum in a solid solution of CdMnTe [7] with the measured values [8]

The PBE0 hybrid functional allows to correct significantly the values of the $3 d$ electron energies in crystals containing $d$ or $f$ transition metals (TMs). This approach is implemented within the ABINIT code [9]. Our recent comparative calculations have confirmed that the use of the hybrid functional leads to the parameters of the electronic structure in ZnSe:TM crystals, which are markedly different from those [10] obtained using the conventional GGA functional [11].

The purpose of this work is a comparative study of the electronic and magnetic properties of $\mathrm{ZnS}: \mathrm{Cr}$, $\mathrm{ZnS}: \mathrm{Fe}$ and ZnS:Cr:Fe crystals, in which $3 d$ transition element replaces the $\mathrm{Zn}$ atom. Highly correlated $3 d$ electrons are described using the PBE0 hybrid functional, which allows partial elimination of the selfinteraction error (SIE) of the latter.

\section{CALCULATION}

The PBE0 hybrid functional allows to correct significantly the values of band gaps in crystals, especially for materials containing $d$ or $f$ transition elements. This approach combines the LDA (GGA) with the HartreeFock exact exchange for $d$ or $f$ electrons, in the exchange-correlation energy functional, as implemented within the ABINIT code [9].

We solve the Schrödinger equation on the basis of projector augmented waves (PAW) [12], which combines the features of pseudopotential approaches and 
the all-electron method of augmented plane waves (APW). In the PAW and APW methods, the crystal is divided into two regions. The first region is inside the atomic spheres, and the second one is interspherical. In the APW approach, wave functions of both regions are combined on the surface of the sphere to ensure continuity throughout space. In the PAW method, augmentation is performed using a projection procedure.

The all-electron wave and pseudo-wave functions are connected as follows [12]:

$$
\left|\psi_{n}(\mathbf{r})\right\rangle=\tau \mid \tilde{\psi}_{n}(\mathbf{r})>,
$$

where the operator converts a pseudo-wave function $\left|\tilde{\psi}_{n}(\mathbf{r})\right\rangle$ into an all-electron wave function $\left|\psi_{n}(\mathbf{r})\right\rangle$. The explicit form of the operator follows from Eq. (1):

$$
\tau=1+\sum_{a} \sum_{i}\left(\left|\phi_{i}^{a}>-\right| \tilde{\phi}_{i}^{a}>\right)<\tilde{p}_{i}^{a} \mid
$$

where $\left|\phi_{i}^{a}(\mathbf{r})\right\rangle$ is the atomic wave, $\left|\tilde{\phi}_{i}^{a}(\mathbf{r})\right\rangle$ is the pseudo-wave, and $<\tilde{p}_{i}^{a} \mid$ is the projector function. The stationary Schrödinger equation,

$$
H\left|\psi_{n}>=\varepsilon_{n}\right| \psi_{n}>\text {, }
$$

taking into account (2), takes the following form [12]:

$$
\tau^{+} H \tau\left|\tilde{\psi}_{n}>=\tau^{+} \tau\right| \tilde{\psi}_{n}>\varepsilon_{n},
$$

in which the required electron spectrum is the same as in Eq. (4). The idea of the PAW method is to convert the Schrödinger equation to an equation in which the unknown state function is $\left|\tilde{\psi}_{n}\right\rangle$. If it is found, then with the help of (1) the all-electron wave function is obtained. Through the latter we find the electron density and the corresponding Hartree potential. The exchange-correlation potential was chosen in the form of PBE0 [4, 11], according to which the exchangecorrelation energy

$$
E_{x c}^{P B E 0}[\rho]=E_{x c}^{P B E}[\rho]+\alpha\left(E_{x}^{H F}\left[\psi_{3 d}\right]-E_{x}^{P B E}\left[\rho_{3 d}\right]\right),
$$

where $\mathrm{PBE}$ corresponds to the generalized gradient approximation (GGA-PBE) of the exchange-correlation functional [11], and $E_{x}^{H F}$ is the exchange energy in the
Hartree-Fock theory. The recommended value of the mixing factor $\alpha$ is equal to 0.25 . In formula (5), the exchange energy, in which the SIE of $3 d$ electrons is the largest, is partially subtracted. In fact, these electrons move in narrow energy bands with a high density of states (DOS). In the included exact term of the exchange energy, the SIE is absent in general. Neglecting the second term in formula (6) leads to the conventional GGA-PBE exchange-correlation functional suitable for describing materials with $s(p)$ electrons. All calculations were performed using the ABINIT program [9], in $2 \times 2 \times 2$ sphalerite supercells containing 64 atoms. A substitutional defect in the $\mathrm{Zn}_{32} \mathrm{~S}_{32}$ supercell of one $\mathrm{Zn}$ atom by a transition element $\mathrm{T}$, i.e., $\mathrm{Zn}_{31} \mathrm{~T}_{1} \mathrm{~S}_{32}$, wass considered. The calculations were performed on the basis of PAW. The following valence configurations of atoms were selected: $\mathrm{Zn}: 3 d^{10} 4 s^{2}$, S: $3 s^{2} 3 p^{4}$, Cr: $3 s^{2} 3 p^{6} 3 d^{5} 4 s^{1}$, and Fe: $3 s^{2} 3 p^{6} 3 d^{6} 4 s^{2}$. Basic functions and pseudopotentials (PAW) were generated using AtomPAW code [13]. The calculation of the wave function was performed on the basis of plane waves determined by the maximum kinetic energy $\varepsilon_{c u t}=44$ Ry on a spatial grid of $90 \times 90 \times 90$. The electron density and potentials were calculated on a denser grid of $180 \times 180 \times 180$ determined by an energy $\varepsilon c u t=156$ Ry.

\section{RESULTS AND DISCUSSION}

\subsection{Electronic and Magnetic Properties of ZnS:Cr Crystal}

Fig. 1a and Fig. 1b show the electronic energy spectra of $\mathrm{ZnCrS}$ crystal corresponding to spin up and down, respectively. Fig. 1a detects the presence of the $3 d$ states of the $\mathrm{Cr}$ atom in the vicinity of the Fermi level, but below the latter. For states with spin up, we have a direct optical band gap at the $\Gamma$ point of $0.63 \mathrm{eV}$ and a fundamental gap $(\Gamma-\mathrm{R})$ of $0.62 \mathrm{eV}$. For electrons with spin down, the direct optical gap at the $\Gamma$ point equals to the fundamental one, and its value is $2.11 \mathrm{eV}$. The magnetic moment of the $\mathrm{Cr}$ atom inside the augmentation sphere is $2.84 \mu \mathrm{B}$, the total moment of all atomic spheres is $2.89 \mu \mathrm{B}$, and the total magnetic moment of the supercell is $4.00 \mu \mathrm{B}$. Fig. 1c shows that the top of the valence band is formed by the Cr $3 d$ electrons and to a lesser extent by the $\mathrm{S} p$ electrons. The bottom of the conduction band is formed by the $\mathrm{Zn} s$ electrons. The $3 d$ electrons of the $\mathrm{Cr}$ atom move in narrow energy bands with large DOS values, so the use of hybrid functional (5) is needed.
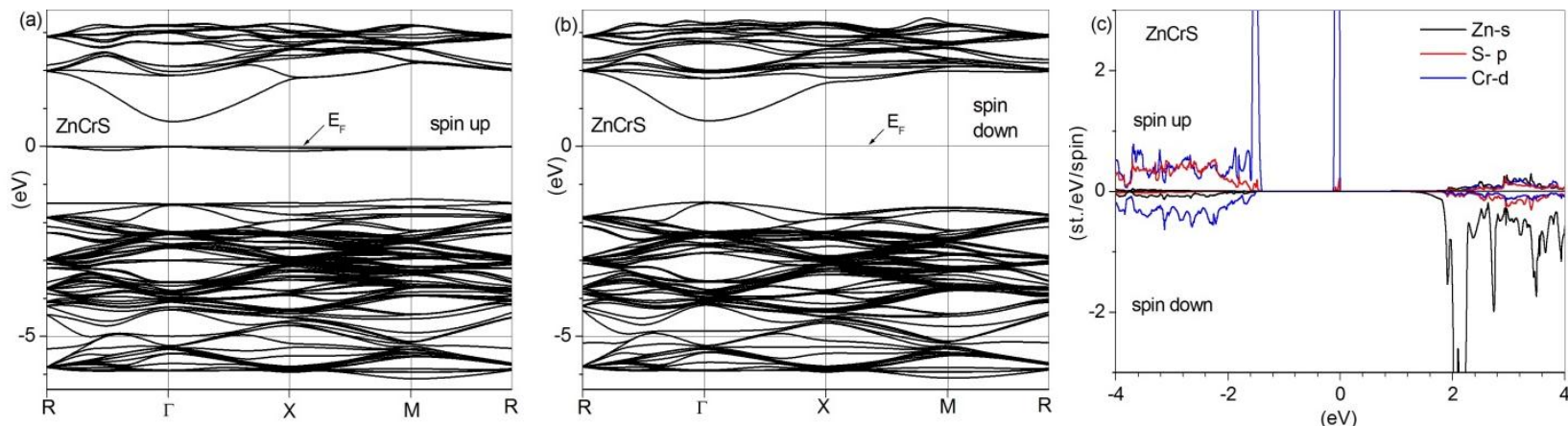

Fig. 1 - The spin-resolved electronic structure (a, b) and DOS (c) of ZnS:Cr crystal obtained with parameter $\alpha=0.25$ in (5) 


\subsection{Electronic and Magnetic Properties of ZnS:Fe Crystal}

Fig. 2a and Fig. 2b show the electronic energy spectra of $\mathrm{ZnFeS}$ crystal corresponding to spin up and down, respectively. Fig. $2 \mathrm{~b}$ detects the presence of the $3 d$ states of the Fe atom in the vicinity of the Fermi level, but higher than the latter. For states with spin up, we have direct optical and fundamental gaps at the
$\Gamma$ point of about $1.96 \mathrm{eV}$. The local magnetic moment of the Fe atom inside the augmentation sphere is $3.29 \mu \mathrm{B}$, the total moment of all atomic spheres is $3.46 \mu \mathrm{B}$, and the total magnetic moment of the supercell is $4.00 \mu \mathrm{B}$. Fig. 2c reveals that the top of the valence band is formed by the $3 d$ electrons of the Fe atom and $p$ electrons of the $\mathrm{S}$ atom. The bottom of the conduction band is formed by the $3 d$ electrons of the Fe atom.
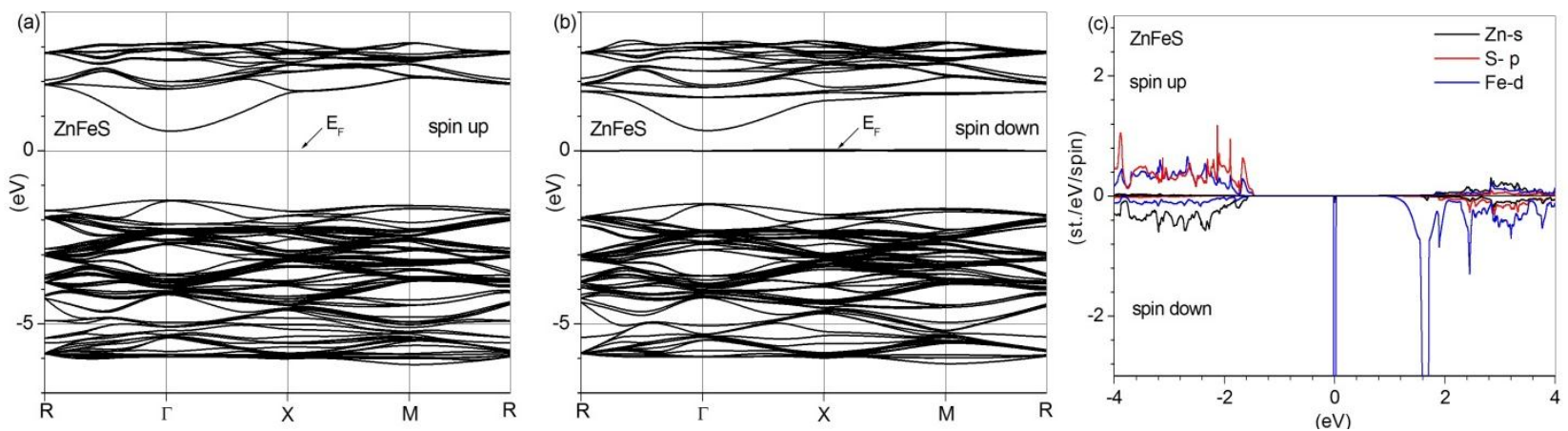

Fig. 2 - The spin-resolved electronic structure (a, b) and DOS (c) of ZnS:Fe crystal obtained with parameter $\alpha=0.25$ in (5)

\subsection{Electronic and Magnetic Properties of ZnS:Cr:Fe Crystal Obtained with the Parameter Value $\alpha=0.25$}

Fig. $3 \mathrm{a}$ and Fig. 3b show the electronic energy spectra of $\mathrm{ZnCrFeS}$ crystal corresponding to spin up and down, respectively. Fig. $3 \mathrm{~b}$ detects the presence of the $3 d$ states of the Cr atom with spin up and $3 d$ states of the Fe atom with spin down in the vicinity of the Fermi level. For states with spin up, we have direct optical and fundamental gaps at the $\Gamma$ point of about $0.60 \mathrm{eV}$, and the value of the fundamental indirect gap $(\Gamma-R)$ is $0.59 \mathrm{eV}$. The magnetic moment of the $\mathrm{Cr}$ atom inside the augmentation sphere is $2.85 \mu \mathrm{B}, \mathrm{Fe}-3.30 \mu \mathrm{B}$, the total moment of all atomic spheres is $6.37 \mu \mathrm{B}$, and the total magnetic moment of the supercell is $8.04 \mu \mathrm{B}$.
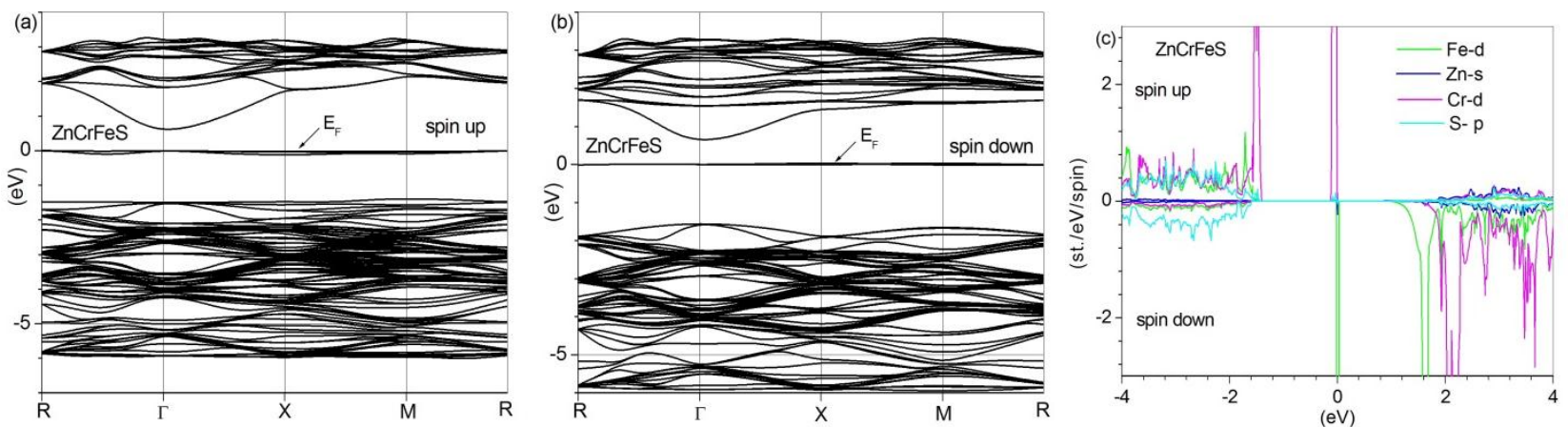

Fig. 3 - The spin-resolved electronic structure (a, b) and DOS (c) of ZnS:Cr:Fe crystal obtained with parameter $\alpha=0.25$ in (5)

\subsection{Electronic and Magnetic Properties of ZnS:Cr:Fe Crystal Obtained with the Parameter Value $\alpha=0$}

Fig. 4a and Fig. 4b show the electronic energy bands in $\mathrm{ZnS}: \mathrm{Cr}: \mathrm{Fe}$ crystal obtained with the mixing parameter $\alpha=0$. This crystal has an optical gap of $0.769 \mathrm{eV}$ at the $\Gamma$ point and an indirect fundamental gap $(\Gamma-\mathrm{R})$ of $0.767 \mathrm{eV}$. The magnetic moment of the $\mathrm{Cr}$ atom inside the augmentation sphere is $2.83 \mu \mathrm{B}$, $\mathrm{Fe}-2.99 \mu \mathrm{B}$, the total moment of all atomic spheres is $6.21 \mu \mathrm{B}$, and the total magnetic moment of the supercell is $8.02 \mu \mathrm{B}$.

Fig. 3 depicts the results obtained taking into account strongly correlated electrons $(\alpha=0.25)$ and Fig. 4 shows the curves found without strong correlation $(\alpha=0)$. Let us compare the parameters of the electronic energy spectra of $\mathrm{ZnS}: \mathrm{Cr}: \mathrm{Fe}$ crystal obtained for the parameter values of 0.25 and 0 . For spin-up states, the optical gaps are equal to $0.59 \mathrm{eV}$ and $0.77 \mathrm{eV}$, respectively. For spin-down states, the corresponding values are $0.60 \mathrm{eV}$ and $0.70 \mathrm{eV}$.

The energy levels of the $3 d$ electrons are especially sensitive to the choice of the exchange-correlation potential. This is clearly seen from a comparison of the graphs shown in Fig. 3 and Fig. 4. The hybrid functional (Eq. (5), $\alpha=0.25$ ) describes $3 d$ electrons in $\mathrm{Cr}$ and $\mathrm{Fe}$ atoms better than the ordinary functional in the GGA-PBE approximation (Eq. (5), $\alpha=0$ ). The hybrid functional for spin-up states (Fig. 3a) and the GGA-PBE one (Fig. 4a) lead to significantly different results concerning the location of the $\mathrm{Cr} 3 d$ levels. Their splitting energies are $1.74 \mathrm{eV}$ and $0.88 \mathrm{eV}$, respectively. For spin-down states (Fig. 3b, Fig. 4b), 
the splitting energies of the Fe $3 d$ levels are equal to $1.65 \mathrm{eV}$ and $0.85 \mathrm{eV}$, respectively. The DOS curves shown in Fig. 3c and Fig. 4c also confirm these differences due to the use of two different exchangecorrelation functionals, namely, the hybrid functional
(5), suitable for describing the $3 d$ electrons with high DOS, and the ordinary one, suitable for describing $s(p)$ electrons, moving in wide energy bands and characterized by moderate values of electronic DOS.
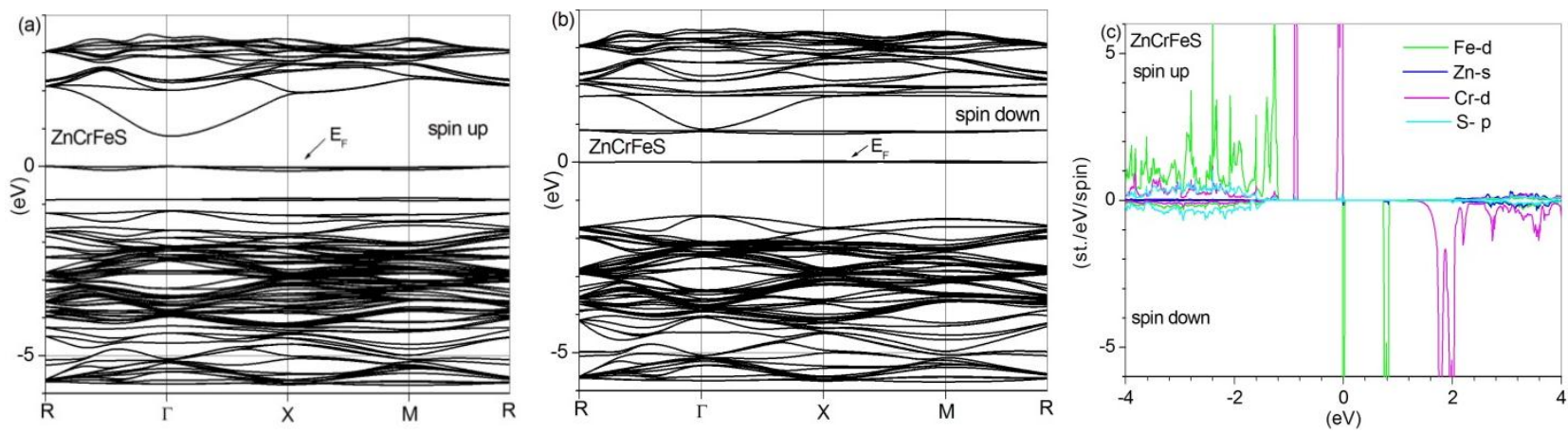

Fig. 4 - The spin-resolved electronic structure (a, b) and DOS (c) of ZnS:Cr:Fe crystal obtained with parameter $\alpha=0$ in (5)

\section{CONCLUSIONS}

Spin-polarized electronic energy band spectra and electronic densities of states in $\mathrm{ZnS}: \mathrm{Cr}, \mathrm{ZnS}: \mathrm{Fe}$, and $\mathrm{ZnS}: \mathrm{Cr}: \mathrm{Fe}$ crystals were obtained for supercells containing 64 atoms. The magnetic moments of the supercells were also found. The calculations were performed using the hybrid exchange-correlation functional PBE0. The difference between $\mathrm{ZnS}: \mathrm{Cr}$ and $\mathrm{ZnS}: \mathrm{Fe}$ materials is as follows. In the first crystal, the electronic $3 d$ levels are located in the upper part of the valence band and near the Fermi level. In the second crystal, the energy levels of the $3 d$ electrons are localized around the Fermi level and in the lower part of the conduction band. The three materials studied here reveal collinear ferromagnetic ordering.

\section{REFERENCES}

1. S.B. Mirov, I.S. Moskalev, S. Vasilyev, V. Smolski, V.V. Fedorov, D. Martyshkin, J. Peppers, M. Mirov, A. Dergachev, V. Gapontsev, IEEE J. Selected Topics Quantum Electron. 24, 1601829 (2018).

2. L.D. DeLoach, R.H. Page, G.D. Wilke, S.A. Payne, W.F. Krupke, IEEE J. Quantum Electron. 32, 885 (1996).

3. S.V. Syrotyuk, O.P. Malyk, J. Nano- Electron. Phys. 11, 06018 (2019).

4. E. Tran, P. Blaha, K. Schwarz, P. Novák, Phys. Rev. B 74, 155108 (2006).

5. Y. Klysko, S. Syrotyuk, Ukr. J. Phys. 66, 55 (2021).

6. S.V. Syrotyuk, Yu.V. Klysko, Condens. Matter Phys. 23, 33703 (2020)

7. S.V. Syrotyuk, O.P. Malyk, J. Nano- Electron. Phys. 11, 01009 (2019).

8. R.Yu. Petrus, H.A. Ilchuk, V.M. Sklyarchuk, A.I. Kashuba, I.V. Semkiv, E.O. Zmiiovska, J. Nano- Electron. Phys. 10, 06042 (2018)
The electronic structures of crystals with impurities of $3 d$ transition elements, found without taking into account strong correlations of the $3 d$ electrons and with the inclusion of the latter in the calculation scheme, reveal quite significant differences. These differences are especially manifested in the localization of the energy levels of the $3 d$ electrons and the energies of their splitting under the action of the crystal field.

\section{ACKNOWLEDGEMENTS}

This contribution was created under the support of the High-Performance Computing Laboratory at the Lviv Polytechnic National University.
9. X. Gonze, F. Jollet, F. Abreu Araujo, D. Adams, B. Amadon, T. Applencourt, C. Audouze, J.-M. Beuken, J. Bieder, A. Bokhanchuk, E. Bousquet, F. Bruneval, D. Caliste, M. Cote, F. Dahm, F. Da Pieve, M. Delaveau, M. Di Gennaro, B. Dorado, C. Espejo, G. Geneste, L. Genovese, A. Gerossier, M. Giantomassi, Y. Gillet, D.R. Hamann, L. He, G. Jomard, J. Laflamme Janssen, S. Le Roux, A. Levitt, A. Lherbier, F. Liu, I. Lukačević, A. Martin, C. Martins, M.J.T. Oliveira, S. Ponce, Y. Pouillon, T. Rangel, G.-M. Rignanese, A.H. Romero, B. Rousseau, O. Rubel, A.A. Shukri, M. Stankovski, M. Torrent , M.J. Van Setten, B. Van Troeye, M.J. Verstraete, D. Waroquiers, J. Wiktor, B. Xu, A. Zhou, J.W. Zwanziger, Comput. Phys. Commun. 205, 106 (2016).

10. Y. Zhang, G. Feng, S. Zhou, Proc. SPIE 9920, Active Photonic Materials VIII, 99200L (SPIE Nanoscience + Engineering: San Diego: California: United States: 2016).

11. J.P. Perdew, K. Burke, M. Ernzerhof, Phys. Rev. Letters 77, 3865 (1996).

12. P.E. Blöchl, Phys. Rev. B. 50, 17953 (1994).

13. N.A.W. Holzwarth, A.R. Tackett, G.E. Matthews, Comput. Phys. Commun. 135, 329 (2001) 


\section{Електронна структура кристала $\mathrm{ZnS}$, легованого одним або двома атомами перехідного металу $(\mathrm{Cr}, \mathrm{Fe})$}

\section{С.В. Сиротюк}

Національний університет "Львівська політехніка", вул. С. Бандери, 12, 79013 Львів, Україна

Розраховані електронні і магнітні властивості кристала $\mathrm{ZnS}$ з домішками перехідних $3 d$ елементів $\mathrm{Cr}$ та $\mathrm{Fe}$, які заміщують атоми Zn. Розрахунки виконані у надкомірках $2 \times 2 \times 2$, які містять 64 атоми. Розглянуті також ці ж надкомірки, які містять одночасно домішки $\mathrm{Cr}$ та Fe. Встановлено, що енергії $3 d$ електронів атома $\mathrm{Cr}$ зі спіном вгору у надкомірці $\mathrm{Zn}_{31} \mathrm{Cr}_{1} \mathrm{~S}_{32}$ локалізовані у вузьких інтервалах в околі рівня Фермі та верху валентної зони. Для станів зі спіном униз цей матеріал виявляе властивості напівпровідника з шириною прямої забороненої зони $2,11 \mathrm{eB}$. Магнітний момент надкомірки становить $4 \mu \mathrm{B}$. Результати розрахунку для надкомірки $\mathrm{Zn}_{31} \mathrm{Fe}_{1} \mathrm{~S}_{32}$ показують, що цей матеріал е прямозонними напівпровідником, ширина міжзонної щілини якого в точці Г дорівнюе 1,96 еВ. $3 d$ електрони зі спінами униз локалізовані у вузьких енергетичних смугах в околі рівня Фермі та дна зони провідності. Значення псевдощілини для електронів зі спіном униз дорівнюе $0,53 \mathrm{eB}$. Магнітний момент надкомірки також дорівнюе $4 \mu \mathrm{B}$. 3 результатів розрахунку для надкомірки $\mathrm{Zn}_{30} \mathrm{Cr}_{1} \mathrm{Fe}_{1} \mathrm{~S}_{32}$ знайдено, що $3 d$ електрони атома $\mathrm{Cr}$ зі спіном вгору локалізовані в околі верху валентної зони та рівня Фермі, який знаходиться всередині валентної зони. Значення оптичної щілини в точщі $Г$ дорівнюе $0,60 \mathrm{eB}, \mathrm{a}$ непрямої фундаментальної щілини $(\Gamma-\mathrm{R})-0.59 \mathrm{eB}$. Значення псевдощілини для електронів зі спінами вниз дорівнюе 0,60 еВ. Магнітний момент надкомірки дорівнюе $8.04 \mu \mathrm{B}$. Розрахунки виконані за допомогою програми ABINIT. Для усунення помилки на самодію $3 d$ електронів атомів $\mathrm{Cr}$ та $\mathrm{Fe}$ застосований гібридний обмінно-кореляційний функціонал РВЕ0.

Ключові слова: ZnS, Структура сфалериту, Домішки $3 d$ елементів, Сильні кореляції, $\mathrm{PBE0,} \mathrm{Елект-}$ ронна структура. 